Int. J. Speleol. 15 (1986), pp. 41-52

\title{
THE SPELEOGENETIC ROLE OF AIR FLOW CAUSED BY CONVECTION. 1st CONTRIBUTION
}

\author{
Arrigo A. Cigna ${ }^{\star}$ \& Paolo Forti* ${ }^{\star}$
}

\begin{abstract}
In the past some authors described the speleogenetic role of convection in phreatic conditions. Similar effects exist also in the air-filled part of vadose passages of caves as a consequence of an air circulation due to a relevant temperature gradient; the effects can be enhanced by the presence of some acids as, e.g., $\mathrm{H}_{2} \mathrm{~S}, \mathrm{H}_{2} \mathrm{SO}_{4}$, etc. In this paper the conditions matching convection and condensation which produce typical forms, very similar to those found under phreatic conditions, are discussed both for limestone and gypsum caves.
\end{abstract}

\section{RIASSUNTO}

In passato vari autori hanno descritto il ruolo speleogenerico di fenomeni convettivi in regime freatico. Effetti analoghi si verificano anche nelle zone emerse di livelli vadosi in conseguenza di una circolazione d'aria provocata dalla presenza di notevoli gradienti termici in atmosfera; questi effetti possono essere esaltati dalla presenza di acidi come, per esempio, $\mathrm{H}_{2} \mathrm{~S}, \mathrm{H}_{2} \mathrm{SO}_{4}$, ecc. In questo lavoro vengono prese in considerazione, sia per grotte nel calcare che nei gessi, le condizioni che possono portare a convenzione e condensazione provocando così forme molto simili a quelle che si riscontrano in condizioni freatiche.

\section{INTRODUCTION}

This paper aims to describe the role of a new speleogenetic effect: the air flow caused by convection. Some typical shapes related to this type of air circulation can be found.

In the past the contribution of convection to speleogenesis was possi-

* Società Speleologica Italiana - Home address: Fraz. Tuffo, I - 14023 COCCONATO At (Italy)

${ }^{\star *}$ Istituto Italiano di Speleologia - Via Zamboni 67, I - 40127 BOLOGNA (Italy) 
bly underestimated and, in any case, considered for the evolution of caves under phreatic conditions only (Bini \& Cappa 1978; Muller, 1974; Muller \& Sarvary, 1977; Rudnicki 1979). Some domes (not related to joints or small ducts) were considered to be caused by these phenomena. The presence of air bubbles was thought to increase the effect of water convection by the corrosion due to condensation (Bini \& Cappa 1978; Muller \& Sarvary, 1977).

Up to now air circulation due to convection was considered to have a negligible role in erosion processes and in a few cases only could produce some condensation followed by solution or corrosion (Pasquini, 1975). A more detailed knowledge of the speleologic mechanisms and the environments where they develop, particularly with reference to the karst and hyperkarst (Cigna, 1978; Forti \& Perna 1986), emphasized the role of convection in cave atmosphere as a major factor in deep karst processes, even though cannot be the most important one.

In this paper, after a short theoretical description of air flow due to convection are given, then examples of caves, both in limestone or gypsum and in lava, where this effect was relevant, are reported. In the past these effects either were not studied or attributed to other causes.

\section{AIR MOVEMENT DUE TO CONVECTION}

This movement is due to the buoyancy of an air mass surrounded by air with a higher density. Air density is determined by its temperature, humidity and pressure, but in a limited environment pressure can be considered to be uniform and therefore it does not play a role in convenction. Air density is given by the following formula:

$$
\mathrm{k}=3.484\left(\mathrm{p}-\mathrm{U}_{\mathrm{r}}{ }^{*} \mathrm{p}_{\mathrm{w}}\right) /(273.15+\mathrm{T})+\mathrm{U}_{\mathrm{r}}{ }^{\star} \mathrm{k}_{\mathrm{W}}
$$

where:

$$
\begin{aligned}
& \mathrm{k}=\text { air density in } \mathrm{kg} / \mathrm{m}^{3} \\
& \mathrm{p}=\text { atmospheric pressure reduced at } 0^{\circ} \mathrm{C} \text {, in } \mathrm{kPa} \\
& \mathrm{U}_{\mathrm{r}}=\text { relative humidity }(=\text { for } 100 \%) \\
& \mathrm{P}_{\mathrm{w}}=\text { vapor partial pressure reduced at } 0^{\circ} \mathrm{C} \text {, in } \mathrm{kPa} \\
& \mathrm{T}=\text { air temperature in }{ }^{\circ} \mathrm{C} \\
& \mathrm{k}_{\mathrm{w}}=\text { vapor density in } \mathrm{kg} / \mathrm{m}^{3}
\end{aligned}
$$


The $\mathrm{k}$ values between 0 and $30^{\circ} \mathrm{C}$ when the relative humidity ranges between 100 and $60 \%$ are reported in Table 1 . these data as well as the plots of fig. 1, point out the greater influence of temperature to determinate air density.

\section{CONVECTION IN THERMAL CAVES}

Some convection forms found in thermal phreatic caves were described by Rudnicki (1979). They are domes and spherical forms, sometimes overlapping each other, of different sizes.

\begin{tabular}{|c|c|c|c|c|c|c|c|c|}
\hline \multirow{2}{*}{$\begin{array}{l}\text { Air } \\
\text { Temp. } \\
{ }^{\circ} \mathrm{C}\end{array}$} & \multicolumn{2}{|c|}{ Vapor } & \multicolumn{6}{|c|}{ Relative humidity } \\
\hline & $\begin{array}{c}\text { pressure } \\
\mathrm{kPa}\end{array}$ & $\begin{array}{l}\text { density } \\
\mathrm{kg} / \mathrm{m}^{3}\end{array}$ & $\begin{array}{l}100 \% \\
\mathrm{~kg} / \mathrm{m}^{3}\end{array}$ & $\begin{array}{c}95 \% \\
\mathrm{~kg} / \mathrm{m}^{3}\end{array}$ & $\begin{array}{c}90 \% \\
\mathrm{~kg} / \mathrm{m}^{3}\end{array}$ & $\begin{array}{c}80 \% \\
\mathrm{~kg} / \mathrm{m}^{3}\end{array}$ & $\begin{array}{c}70 \% \\
\mathrm{~kg} / \mathrm{m}^{3}\end{array}$ & $\begin{array}{c}60 \% \\
\mathrm{~kg} / \mathrm{m}^{3}\end{array}$ \\
\hline 0 & 0.611 & 0.00484 & 1.2725 & 1.2727 & 1.2728 & 1.2731 & 1.2734 & 1.2737 \\
\hline 1 & 0.657 & 0.00520 & 1.2677 & 1.2678 & 1.2680 & 1.2683 & 1.2686 & 1.2689 \\
\hline 2 & 0.705 & 0.00557 & 1.2629 & 1.2630 & 1.2632 & 1.2635 & 1.2639 & 1.2642 \\
\hline 3 & 0.759 & 0.00596 & 1.2580 & 1.2582 & 1.2584 & 1.2587 & 1.2591 & 1.2595 \\
\hline 4 & 0.813 & 0.00637 & 1.2532 & 1.2534 & 1.2536 & 1.2540 & 1.2544 & 1.2548 \\
\hline 5 & 0.872 & 0.00681 & 1.2484 & 1.2487 & 1.2489 & 1.2493 & 1.2497 & 1.2501 \\
\hline 6 & 0.935 & 0.00726 & 1.2437 & 1.2439 & 1.2441 & 1.2445 & 1.2450 & 1.2454 \\
\hline 7 & 1.00 & 0.00776 & 1.2389 & 1.2392 & 1.2394 & 1.2399 & 1.2403 & 1.2408 \\
\hline 8 & 1.07 & 0.00828 & 1.2342 & 1.2345 & 1.2347 & 1.2352 & 1.2357 & 1.2362 \\
\hline 9 & 1.15 & 0.00883 & 1.2294 & 1.2297 & 1.2300 & 1.2305 & 1.2310 & 1.2316 \\
\hline 10 & 1.23 & 0.00941 & 1.2247 & 1.2250 & 1.2253 & 1.2259 & 1.2264 & 1.2270 \\
\hline 11 & 1.31 & 0.0100 & 1.2201 & 1.2204 & 1.2207 & 1.2213 & 1.2219 & 1.2225 \\
\hline 12 & 1.41 & 0.0107 & 1.2154 & 1.2157 & 1.2160 & 1.2167 & 1.2173 & 1.2180 \\
\hline 13 & 1.49 & 0.0114 & 1.2108 & 1.2111 & 1.2115 & 1.2122 & 1.2128 & 1.2135 \\
\hline 14 & 1.60 & 0.0121 & 1.2060 & 1.2064 & 1.2067 & 1.2075 & 1.2082 & 1.2089 \\
\hline 15 & 1.64 & 0.0128 & 1.2021 & 1.2024 & 1.2028 & 1.2035 & 1.2042 & 1.2049 \\
\hline 16 & 1.81 & 0.0137 & 1.1968 & 1.1972 & 1.1976 & 1.1984 & 1.1992 & 1.2000 \\
\hline 17 & 1.93 & 0.0145 & 1.1921 & 1.1925 & 1.1930 & 1.1938 & 1.1947 & 1.1956 \\
\hline 18 & 2.07 & 0.0154 & 1.1873 & 1.1877 & 1.1882 & 1.1891 & 1.1901 & 1.1910 \\
\hline 19 & 2.20 & 0.0163 & 1.1826 & 1.1831 & 1.1836 & 1.1846 & 1.1856 & 1.1866 \\
\hline 20 & 2.33 & 0.0173 & 1.1781 & 1.1786 & 1.1791 & 1.1802 & 1.1812 & 1.1822 \\
\hline 21 & 2.48 & 0.0183 & 1.1734 & 1.1739 & 1.1745 & 1.1756 & 1.1767 & 1.1778 \\
\hline 22 & 2.64 & 0.0194 & 1.1687 & 1.1692 & 1.1698 & 1.1710 & 1.1722 & 1.1734 \\
\hline 23 & 2.81 & 0.0206 & 1.1640 & 1.1646 & 1.1652 & 1.1665 & 1.1677 & 1.1690 \\
\hline 24 & 2.99 & 0.0218 & 1.1592 & 1.1599 & 1.1605 & 1.1619 & 1.1632 & 1.1645 \\
\hline 25 & 3.17 & 0.0231 & 1.1546 & 1.1553 & 1.1560 & 1.1574 & 1.1588 & 1.1602 \\
\hline 26 & 3.37 & 0.0245 & 1.1499 & 1.1506 & 1.1514 & 1.1528 & 1.1543 & 1.1558 \\
\hline 27 & 3.57 & 0.0258 & 1.1451 & 1.1459 & 1.1467 & 1.1482 & 1.1498 & 1.1514 \\
\hline 28 & 3.79 & 0.0273 & 1.1404 & 1.1412 & 1.1420 & 1.1437 & 1.1453 & 1.1470 \\
\hline 29 & 4.01 & 0.0288 & 1.1356 & 1.1365 & 1.1374 & 1.1391 & 1.1409 & 1.1426 \\
\hline 30 & 4.23 & 0.0303 & 1.1310 & 1.1319 & 1.1328 & 1.1346 & 1.1364 & 1.1383 \\
\hline
\end{tabular}

Table 1 - Air density in function of temperature and relative humidity. Values are referred to a pressure of $100 \mathrm{kPa}=1 \mathrm{bar}=750 \mathrm{~mm} \mathrm{Hg}$. 


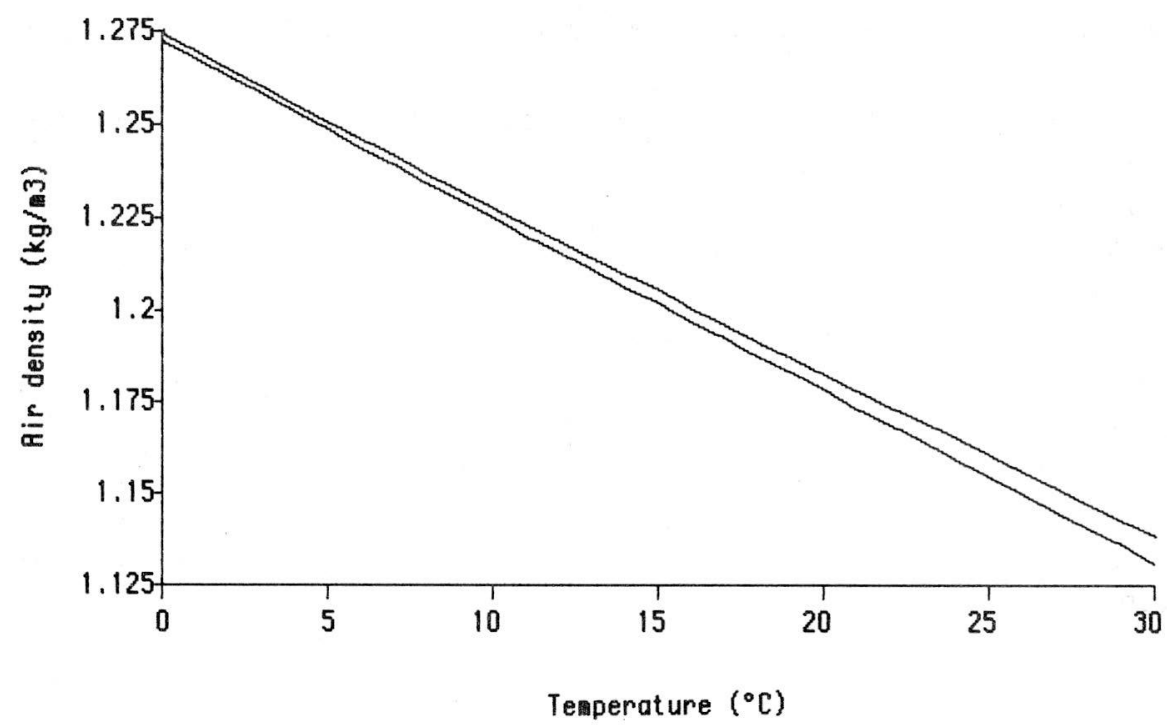

Fig. 1 - Air density in function of temperature: lower curve $100 \%$ relative humidity; upper curve $50 \%$ relative humidity. Values are reffered to a pressure of $100 \mathrm{kPa}=1 \mathrm{bar}=750 \mathrm{~mm} \mathrm{Hg}$.

Research carried out recently on the formations in Grotta Giusti (a thermal cave near Monsummano, Lucca, Italy) pointed out that the cave clouds were heavily corroded by a number of spherical domes also reaching and deepening into the limestone.

The corrosion of these formations are the consequence of a relevant air flow set up when the lowering of the water level started the air convection: air temperature gradient is rather high because the surface water temperature of the lake inside the cave is about $32-34^{\circ} \mathrm{C}$ while the rock wall at the upper levels is below $20^{\circ} \mathrm{C}$. The corrosion is also enhanced by the high concentration of $\mathrm{CO}_{2}$ in the water and, therefore, also in the air and in the water condensing on the cave walls.

The most common morphological feature due to convection in Grotta Giusti is a moltitude of domes or hollow half-spheres in the roof and the walls in the higher series of the cave. The abundance of these forms, quite unrelated to joints or fractures, show that now the cave development is only due to convection processes (condensation and corrosion).

Due to the strong air flow, the condensation at the top of the domes is faster than the corrosion inside the domes and some furrows develop be- 
low the domes. The edges of these furrows are decorated by coral-like formations.

To evaluate the actual importance of the corrosion due to convection, a simple calculation based on the parameters measured in Grotta Giusti was developed. In this cave the air temperature in the lower series is about $34^{\circ} \mathrm{C}$ and corresponds to that of a lake fed by thermal water. In the upper series the rock temperature is $20^{\circ} \mathrm{C}$.

By assuming an atmospheric pressure of $100 \mathrm{kPa}(750 \mathrm{~mm} \mathrm{Hg})$ and a relative humidity of $100 \%$ the absolute humidity at $34^{\circ} \mathrm{C}$ is $35.13 \mathrm{~g}$ of water per $\mathrm{kg}$ of air, while at $20^{\circ} \mathrm{C}$ it is only $14.95 \mathrm{~g} / \mathrm{kg}$ : therefore the difference, $20.18 \mathrm{~g} / \mathrm{kg}$ (corresponding to $24 \mathrm{~g}$ per $\mathrm{m}^{3}$ of air), is the condensed water. The air flow due to the rather high temperature gradient was measured to have an average velocity of $1 \mathrm{~m} / \mathrm{sec}$ over a section of $4 \mathrm{~m}^{2}$. Then it can be obtained by:

$$
24 \mathrm{~g} / \mathrm{m}^{3} * 4 \mathrm{~m} / \mathrm{sec}=96 \mathrm{~g} / \mathrm{sec}
$$

i.e., nearly $100 \mathrm{~g} / \mathrm{sec}$ of condensation water. In one day the total amount of condensation water is

$$
100 \mathrm{~g} / \mathrm{sec} * 86400 \mathrm{sec} / \text { day }=8640 \text { litres }
$$

The concentration of $\mathrm{CO}_{2}$ in air was determined to be about 1000 $\mathrm{ppm}$ corresponding to $0.038 \mathrm{mmoles} /$ litre in water by applying the formula:

$$
\mathrm{K}_{\mathrm{c}}=\frac{\left[\mathrm{CO}_{2}{ }^{\circ}\right](\text { in moles } / \text { litre })}{\mathrm{p}(\text { in atm })}
$$

The equilibrium constant $\mathrm{K}_{\mathrm{c}}$ at $20^{\circ} \mathrm{C}$ is 0.0383 (Siedell, 1958; Picknett et al, 1976). A concentration of $\mathrm{CO}_{2}$ of $0.038 \mathrm{mmoles} /$ litre will dissolve about $73 \mathrm{mg} /$ litre of $\mathrm{CaCO}_{3}$ (Cigna, 1975, p. 400). Therefore in one day the total amount of $\mathrm{CaCO}_{3}$ dissolved would be:

$$
0.073 \mathrm{~g} / \text { litre } * 8640 \text { litres }=630 \mathrm{~g}
$$

Such a rather high amount is a clear indication of the importance of this phenomenon even if an equilibrium in unlikely to be attained and therefore the value must be considered as an upper limit. 


\section{CONVECTION IN PRESENCE OF STRONG ACIDS}

In normal caves the thermal gradient is generally small and the convection can produce a slow air flow. But in particular conditions, e.g. in presence of $\mathrm{H}_{2} \mathrm{~S}$, the effects can be enhanced by the corrosion due to $\mathrm{H}_{2} \mathrm{SO}_{4}$ formed by oxidation of the $\mathrm{H}_{2} \mathrm{~S}$ (Perna \& Pozzi, 1959; Forti \& Perna, 1986). The effect of $\mathrm{H}_{2} \mathrm{SO}_{4}$ on the development of karst phenomenon was extensively described also by Morehouse (1968). By assuming that the reaction of $\mathrm{H}_{2} \mathrm{SO}_{4}$ with the limestone will proceed with this formula:

$$
\mathrm{H}_{2} \mathrm{SO}_{4}+\mathrm{CaCO}_{3}+\mathrm{H}_{2} \mathrm{O}=\mathrm{CaSO}_{4}{ }^{\star} 2 \mathrm{H}_{2} \mathrm{O}+\mathrm{CO}_{2}
$$

and the condensed water has a measured $\mathrm{pH}=3$, it can be easily calculated that the reactants and the products will have the following concentrations:

$$
\begin{array}{ll}
\mathrm{H}_{2} \mathrm{SO}_{4} & 0.049 \mathrm{~g} / \text { litre } \\
\mathrm{CaCO}_{3} & 0.050 \mathrm{~g} / \text { litre } \\
\mathrm{CaSO}_{4}{ }^{*} 2 \mathrm{H}_{2} \mathrm{O} & 0.086 \mathrm{~g} / \text { litre } \\
\mathrm{CO}_{2} & 0.022 \mathrm{~g} / \text { litre }
\end{array}
$$

Water with $22 \mathrm{mg} /$ litre of $\mathrm{CO}_{2}$ dissolves about $180 \mathrm{mg} /$ litre of $\mathrm{CaCO}_{3}$ (Cigna, 1975). On account of the common ion effect due to $\mathrm{CaSO}_{4}$ (Picknett, 1977) a reduction of about $20 \%$ can be considered. But in such conditions the ionic strenght of the solution is sufficient to lower the activity of the $\mathrm{Ca}^{++}$ions to a value of about $70 \%$ of its concentration. Therefore the final result of these two apposite effects causes a slight increase in the solubility of $\mathrm{CaCO}_{3}$ which becomes something higher than $200 \mathrm{mg} / \mathrm{l}$; therefore the total amount of $\mathrm{CaCO}_{3}$ dissolved would be:

$$
200+50=250 \mathrm{~g} / \text { litre }
$$

this value of about $250 \mathrm{~g}$ /litre corresponds to that of a rather aggressive water.

An example of an air flow (due to convection) with $\mathrm{H}_{2} \mathrm{SO}_{4}$ is found in the Grotta Grande del Vento (Ancona, Italy) in the area called "Fiabilandia". Two potholes connect the lower series, where sulfide containing water flows, to the dry upper series of the cave. The roof of the latter series is characterized by many domes or huge "scallops" of different sizes and 
partially overlapping each other. Their surface is covered by a thin layer of $\mathrm{CaSO}_{4}{ }^{\star} 2 \mathrm{H}_{2} \mathrm{O}$. The layer is thicker where the gypsum is not eluted by the condensation water.

The presence of the features here described suggests the possibility of the major role played also in the past by such a process in the development of large caverns. This hypothesis is supported by the existence of large gypsum deposits in many areas along the cave. A systematic research on this particular problem is expected to be carried out in the near future.

A similar hypothesis could also be made for Carlsbad Caverns where thick gypsum deposits are found in chambers whose roofs have many domes and hollow half-cavities. A speleogenetic process based on convection could be envisaged instead of a phreatic origin, which was considered valid up to now.

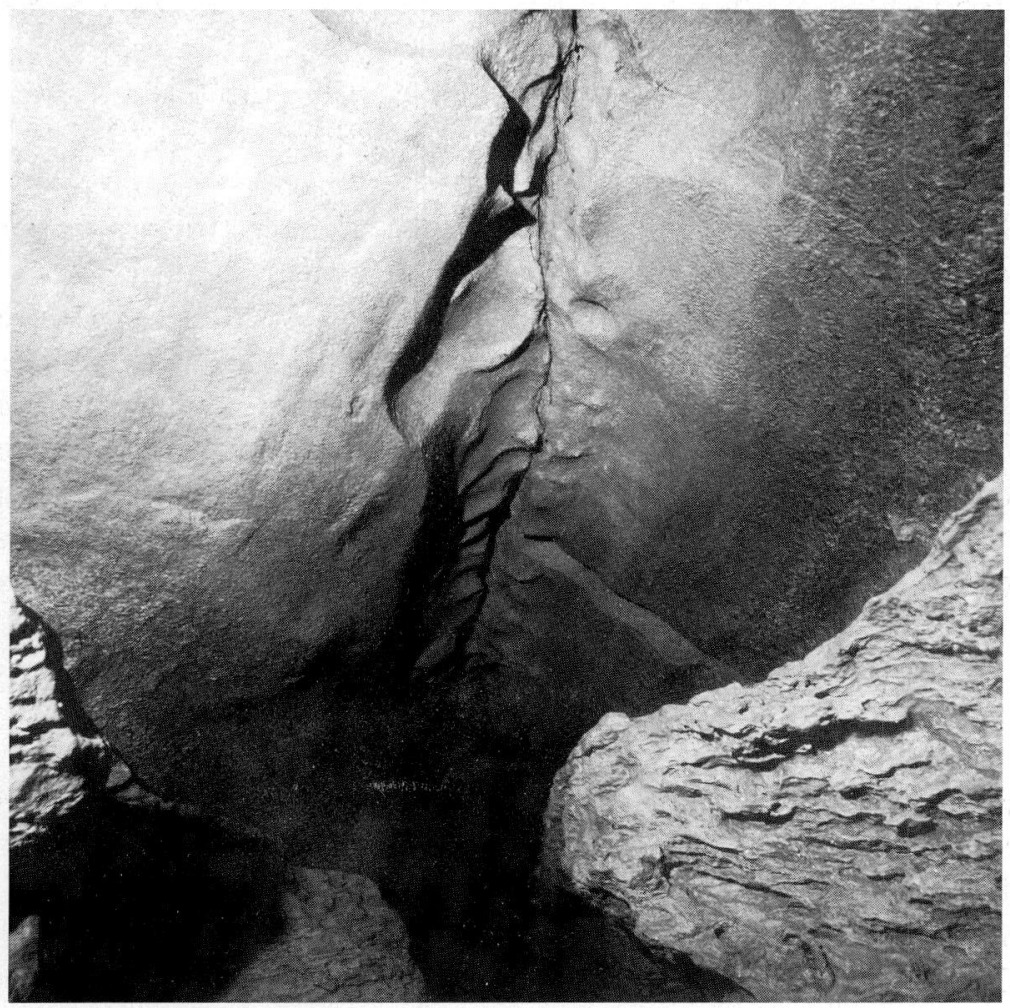

Fig. 2 - Solutional domes caused by condensation due to gas convection on the ceiling of a gypsum cave. An evidence of their genesis is that the evolution of the domes is still going on nowaday, while all the gallery is completely fossil (Photo by P. Forti). 


\section{CONVECTION IN CAVES DEVELOPED IN WATER SOLUBLE ROCKS}

The air movement due to convection is a rather common feature and its speleogenetical role may be quite important in this kind of caves (Fig. 2). Nevertheless if the climate is too arid the condensation cannot occur and the convection has no consequences from the point of view of the cave development: this was the case of the halite caves of Mount Sedom (Israel) (Donini et al. 1985).

On the contrary, in regions with continental temperated climate the convection can produce large amount of condensation water. A typical example can be found in many gypsum caves near by Bologna (Italy). Caves with large exchanges between internal and external air (e.g. the cave system Grotta della Spipola - Grotta dell'Acquafredda) develop many corrosion forms (domes, scallop-like cavities, hollow half-spheres, etc.) on the walls and the roof up to some tens of metres inside the entrance. In some instances these forms can be found further inside up to more than 100 metres.

In general these caves had a tectonic or a graviclastic origin but the corrosion features actually dominate the cave development in the vicinity of the entrances. The original features can be found in areas not influenced by convection.

Near the entrance of the Grotta dell'Acquafredda on a typical summer day, the outside air temperature can be about $30^{\circ} \mathrm{C}$ with a relative humidity of $65 \%$ while the inside air temperature is $10^{\circ} \mathrm{C}$. If the atmospheric pressure is assumed to be $100 \mathrm{kPa}$ as in the other examples, the absolute humidity at saturation of the inside air is $7.76 \mathrm{~g} / \mathrm{kg}$. Therefore, on account of the outside air entering the cave, the condensation water will be 10.23 $\mathrm{g} / \mathrm{kg}$ or $12.59 \mathrm{~g}$ of water per $\mathrm{m}^{2}$ of air. The entrance has a section of $4 \mathrm{~m}^{2}$ and the average air velocity is about $3 \mathrm{~m} / \mathrm{sec}$. In these conditions:

$$
4 \mathrm{~m}^{2} * 3 \mathrm{~m} / \mathrm{sec} * 68.400 \mathrm{sec}=10^{6} \mathrm{~m}^{3} \text { of air }
$$

per day enter the cave; the condensation water will be:

$$
12.59 \mathrm{~g} / \mathrm{m}^{3}{ }^{*} 10^{6} \mathrm{~m}^{3}=13{ }^{*} 10^{6} \mathrm{~g} \text { of water per day. }
$$

The solubility of $\mathrm{CaSO}_{4}{ }^{*} 2 \mathrm{H}_{2} \mathrm{O}$ being about $2.5 \mathrm{mg} /$ litre, the total amount dissolved in one day might be: 


\section{0 litres ${ }^{*} 2.5 \mathrm{~g} /$ litre $=33 \mathrm{~kg}$}

of gypsum. Of course this figure is probably an upper limit of the actual amount because the solution of $\mathrm{CaSO}_{4}{ }^{*} 2 \mathrm{H}_{2} \mathrm{O}$ will not reach a saturation condition. Also in this case the activity plays a noticeable role, due to the concentration degree of the solution. Therefore it can be assumed that the activity effect at least balances the lack of full saturation of the solution.

In the case of other water soluble rocks, as quartzites, the the amount of material dissolved is smaller because at $10^{\circ} \mathrm{C}$ the solubility of quartz, which is the main constituent of quartzites, is about $8 \mathrm{mg} /$ litre, i.e. about 300 times less than gypsum solubility. By way of comparison, in the same conditions of the previous example, the amount of quartzite dissolved would have been about $100 \mathrm{~g} /$ day, which are not negligible at alla because of the very long time necessary for the cave.

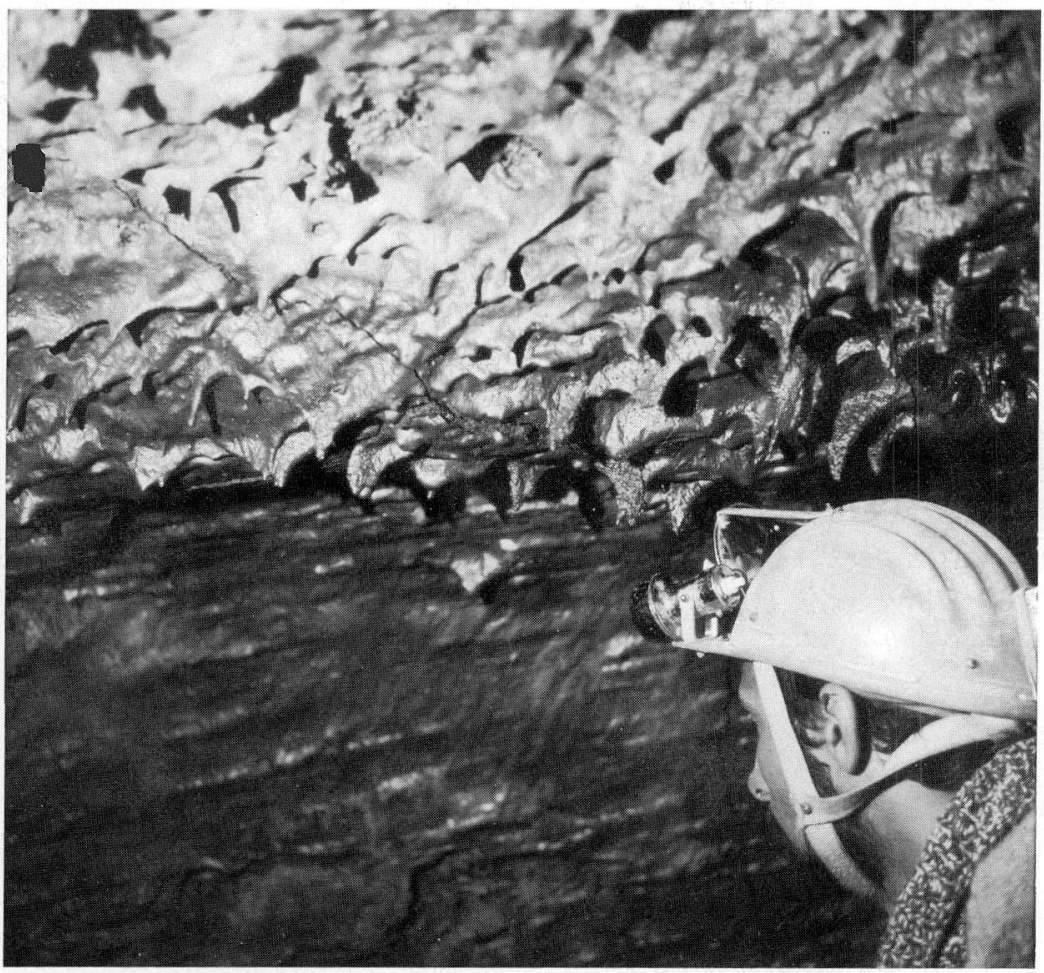

Fig. 3 - Pendants generated by the melting of the ceiling in a lava tbe. The melting is caused by local increase of roof temprature due to oxidations occurring in gas phase (Photo by P. Forti). 


\section{CONVECTION IN HYPOKARST CAVES}

The lava caves are the natural caves where the gas flow due to convection has the most important role in the speleogenetic process as a whole. In

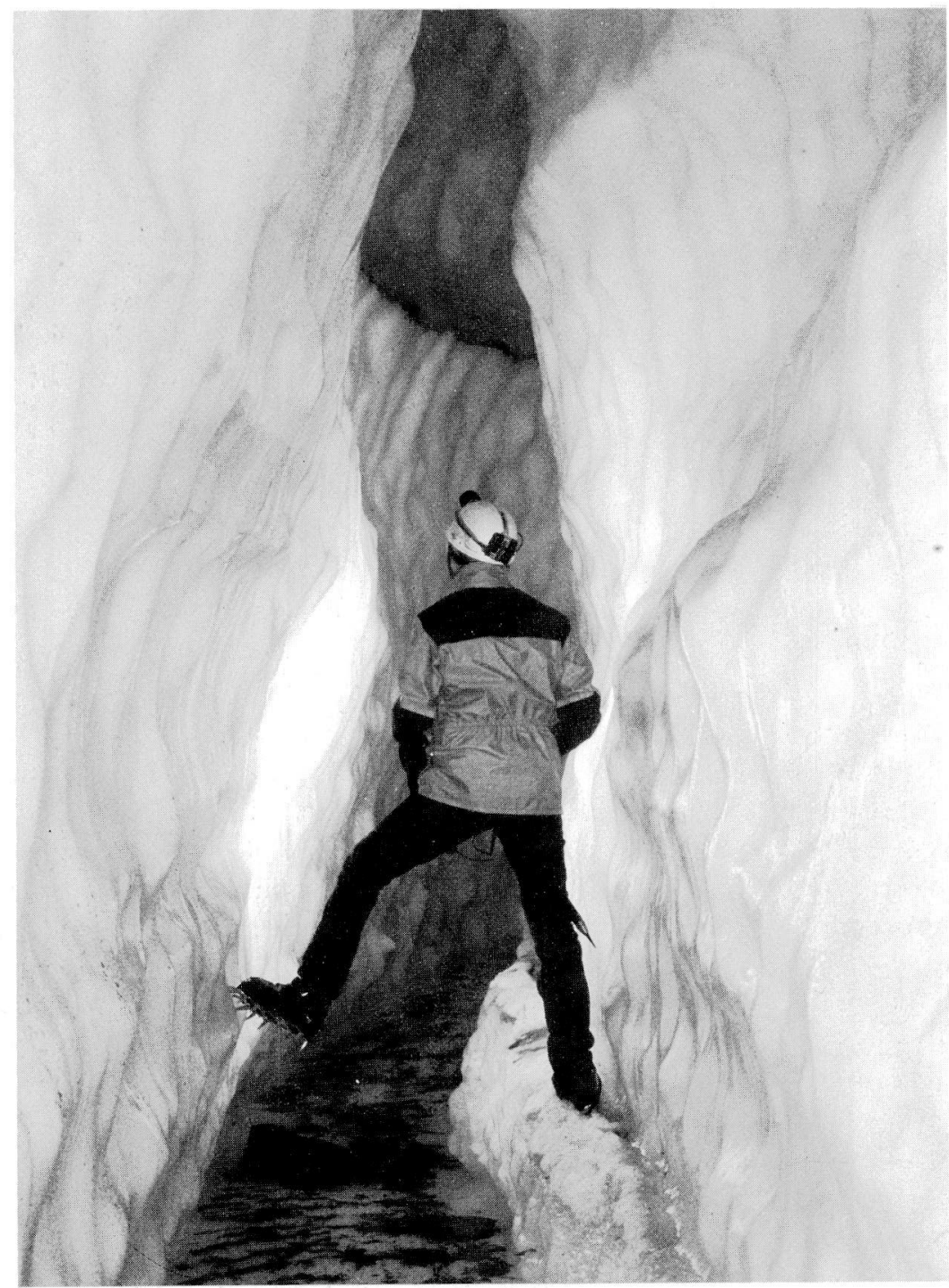

Fig. 4 - Large scallops developed via gas convection in an ice cave (Photo by M. Vianelli). 
fact in these caves the forms produced by convection are not the domes (which, on the other hand, are often absent) and the scallop-like features but particularly the formations as the lava stalactites and stalagmites (Fig. 3).

Such formations are due to a local increase of the roof temperature on account of oxidation reactions which start when the lava tube is no longer completely filled with liquid lava (Wood, 1976). This effect is peculiar of the lava tubes and, of course, there is no equivalent effect in karst caves: therefore it can be concluded that the evolution of lava caves is greatly influenced by gas flow due to convection.

The speleogenesis of another type of hypokarst (Cigna, 1978; 1983; 1986) caves, the ice caves, is definitely influenced by the gas flow due to convection: many big "scallops" in the roof and the walls of potholes (Fig. 4) could be attributed to this cause. Some formations are also fed by the fusion water originated by the gas flow.

The mechanism of convection, therefore, seems to be particularly important for the speleogenesis of hypokarst caves in general.

\section{CONCLUSIONS}

Air flow (or, more generally, gas flow) due to convection plays a role, in the different phases of cave formation, which is more common and important than it was thought up to now. The effects are noticeable not only when a temperature gradient is high (as in thermal caves, rather often, it is) but also when the condensed water is very aggressive on account of strong acids $\left(\mathrm{H}_{2} \mathrm{~S}\right.$ and $\left.\mathrm{H}_{2} \mathrm{SO}_{4}\right)$ or when the condensed water is more abundant as a consequence of a high relative humidity of the air entering the caves in summer time. For hypokarst caves (lava and ice caves) the effects are more important because they also influence the genesis of many formations.

The typical forms which can be attributed to the air flow due to convection are domes, hollow half-spheres, scallop-like features, etc. often rather shallow and overlapping each other, leading to large "scallops" in the roof. Sometimes coral-like formations grow along the edges of some domes. Stalactites and stalagmites are also formed in hypokarst caves.

The air flow due to convection is a foundamental speleogenetical mechanism which deserve much more interest. The knowledge of its effects is far from being exhausted and it is hoped that a great attention will be drawn on this particular topic under different particular conditions. 


\section{REFERENCES}

BINI \& CAPPA G., 1978: Considerazioni sulla morfologia delle cupole. Quaderni Museo Speleol. "G. Rivera", L'Aquila 4 (7/8):47/62.

Cigna A. A., 1975: Considerazioni sulle teorie speleogenetiche. Atti del Seminario di Speleogenesi, Villa Monastero, Varenna 5-8 Oct. 1972; in: Le Grotte d’Italia, s. 4,4:391/408.

Cigna A. A., 1978: A Classification of Karstic Phenomena. Int. J. Spelology, 10 (1):3/9.

CignA A. A., 1983: Sulla Classificazione dei fenomeni carsici. Atti XIV Congresso Nazionale dei Speleologia, Bologna 2-5 Sept., 1982; in: Le Grotte d'Italia s. 4.11:497/505.

CignA A. A., 1986: Some remarks on phase-equilibria of evaporites and other karstifiable rocks. Proc. Int. Symp. on Evaporite Karst, Bologna 22-25 Oct. 1985; in: Le Grotte d'Italia s 4,12:201-208

Donini G., Rossi G., Forti P., Buzio A., Calandri G., 1986: Monte Sedom: ricerche sul carsismo sviluppatosi su un diapiro nella depressione del Mar Morto. Società Speleologica Italiana, Commiss. Grandi Spedizioni, 2:23/40.

FORTI P. \& PERNA G., 1986: L'ipercarsismo con particolare riguardo all'Iglesiente (Sardegna Sud Occidentale). Atti Museo Sc. Nat. Trento, XXXIV (2-3):85-99.

FORTI P. \& UTILI F., 1984: Le concrezioni della Grotta Giusti. Speleo, Firenze, 12:17/25.

HiLl C. \& ForTI P., 1986: Cave Minerals of the World. Natl. Speleol. Society, USA :272pp.

MOREHOUSE D. F., 1968: Cave development via the sulphuric acid reaction. Natl. Speleol. Soc. Bull., 30 (1):1/10.

Muller P., 1974: A melegforrasbarlangok ës gòmbfulkek keletkesësërol. Karszt és Barlang, $1: 7 / 10$.

MULLER P. \& SARVARY I., 1977: Some aspects of developments in Hungarian speleological theories during the last 10 years. Karszt és Barlang, special issue: 53/60.

PASQUINI G., 1975: Considerazioni sulla percolazione e sulla condensazione. Atti del Seminario di Speleogenesi, Villa Monastero, Varenna 5-8 ottobre 1972; in: Le Gotte d'Italia s. 4.4:323/329.

PiCKnett R. G., Bray L. G., Stenner R. D., 1976: The Chemistry of Cave Waters, in: Ford T. D. \& Cullingford C.N.D. (Eds.) - The Science of Speleology. Academic Press, London: 212/266.

PICKNETT R. G., 1977: Foreign substances and calcite solubility in carbonated waters. Proc. 7th Int. Speleol. Congr., Sheffield, England: 348/351.

PERNA G. \& POZzI R., 1959: Osservazioni su alcuni fenomeni concrezionari della Grotta del Fiume (Ancona). Rass. Speleol. Ital., 11 (1):3/17.

RUDNICKI J., 1979: Role of convection in shaping subterranean karst forms. Kras i speleologia $11(2): 92 / 100$.

SIEDELL A., 1958: Solubilities of Inorganic and Metal-Organic Compounds. 1, 4th edn., (revised by Linke W. F.), Nostrand Co., Inc., New York.

Woon C., 1976: Caves in rocks of volcanic origin. In: Ford T. D. \& Cullingford C.N.D. (Eds.) - Science of Speleology. Academic Press, London: 127/150. 